\title{
150 years of new beetles (Coleoptera) described in The Canadian Entomologist and associated publications (1868-2017)
}

\author{
P. Bouchard, ${ }^{1}$ A.J. Brunke, A.E. Davies, H. Douglas, \\ A.B.T. Smith, J. Manoogian
}

\begin{abstract}
The Canadian Entomologist and its associated publications (Supplements of The Canadian Entomologist and Memoirs of the Entomological Society of Canada) have served as important outlets for taxonomic contributions on arthropods since 1868. A survey of beetle (Coleoptera) publications therein has revealed that 2276 species-group, 136 genus-group, and seven family-group taxa were first described in 492 scientific articles. New beetles were described in 67 families by 165 authors. We document trends of beetle descriptions over time, by taxonomic group and by the origin of the new taxa. We also provide biographical notices of the entomologists who described the new taxa. We believe that The Canadian Entomologist will continue to be coveted as a suitable outlet for taxonomic works in the future.
\end{abstract}

\section{Introduction}

Beetles (Coleoptera) were on the minds of the founders of The Canadian Entomologist as demonstrated in the very first sentence published in this journal "For a long time, the wielders of the butterfly net and beetle bottle in Canada have been longing for some medium of intercommunication ..." (Bethune 1868a: 1). The first scientific contribution ever published in this journal, entitled "A luminous larva" (Bethune 1868b) where morphological and biological information on a Lampyridae (Coleoptera) larva were provided, is further evidence that members of the emerging Entomological Society of Canada were eager to communicate about this diverse and biologically interesting group of insects. A recent review of the contents published in The Canadian Entomologist revealed that the importance of beetles as research organisms has increased over the last 150 years (Table 2 in Floate and Huber 2018).

Although The Canadian Entomologist publishes a broad range of communications (e.g., original papers on the classification, description, habits, and natural history of insects, accounts of rare species), we focus here only on descriptions of new taxa for a single insect group, the beetles. As presented below, it is clear that The Canadian Entomologist and its associated publications (Supplements of The Canadian Entomologist and Memoirs of the Entomological Society of Canada) served as an important outlet for descriptions of new beetle taxa at the species-group, genus-group, and familygroup ranks. This historical summary of beetle descriptions over the last 150 years also allowed us to document and celebrate the significant scientific contributions of our colleagues and predecessors.

The specific objectives of this article are to provide syntheses of: (1) new beetle descriptions published in The Canadian Entomologist and associated publications from 1868 to 2017; (2) trends of beetle descriptions over time, by taxonomic group and by the origin of the new taxa; and (3) the entomologists who described the new beetle taxa, including information about the location of the institutions where they worked.

Received 18 May 2018. Accepted 26 July 2018. First published online 24 October 2018.

P. Bouchard, ${ }^{1}$ A.J. Brunke, A.E. Davies, H. Douglas, Agriculture and Agri-Food Canada, Canadian National Collection of Insects, Arachnids, and Nematodes, 960 Carling Avenue, Ottawa, Ontario, K1A 0C6, Canada A.B.T. Smith, Canadian Museum of Nature, P.O. Box 3443, Station D, Ottawa, Ontario, K1P 6P4, Canada J. Manoogian, 173 Redpath Drive, Ottawa, Ontario, K2G 6K5, Canada

${ }^{1}$ Corresponding author (e-mail: patrice.bouchard@agr.gc.ca)

Subject editor: Kevin Floate

doi:10.4039/tce.2018.48 


\section{Materials and methods}

We included scientific articles containing descriptions of new Coleoptera taxa published in The Canadian Entomologist (August 1868 to December 2017), the Supplements of The Canadian Entomologist (1955-1963), and the Memoirs of the Entomological Society of Canada (1963-1997). Family assignments were updated to match Bouchard et al. (2011) and Bousquet et al. (2013). Only new taxa that were made available nomenclaturally following articles of the International Code of Zoological Nomenclature (International Commission on Zoological Nomenclature 1999) were tabulated. Following recommendations in a recent amendment of the International Code of Zoological Nomenclature (International Commission on Zoological Nomenclature 2012) we have used the date of the electronic version (i.e., First View) of an article when the electronic version was produced in the year preceding the print version. Original spellings of all names are given (Supplementary Tables S1-S3). In the lists of new taxa, initials are used when two or more authors have the same surname (e.g., H.F. Howden and A.T. Howden).

\section{Results}

\section{New Coleoptera taxa}

A total of 2276 species-group, 136 genusgroup, and seven family-group taxa were first described in 492 scientific articles of The Canadian Entomologist, the Supplements of The Canadian Entomologist, and the Memoirs of the Entomological Society of Canada from 1868 to the end of 2017 (Supplementary Tables S1-S3). The first new beetles were described in 1892 and the rate of descriptions varied greatly over time (Fig. 1). The period between 1900 and 1939 included between 265 and 318 new taxa per decade, a high rate of description that was matched only once again in the 1970s. The 1940s and 1950s saw a sharp decrease in the rate of description of new beetle taxa, with fewer than 100 new taxa described during each decade. A peak of descriptions occurred in the 1970s when 336 new beetle taxa were described. The number of new beetles described by decade has decreased rather consistently since that peak to only 51 during the last seven years.
Eighty-two per cent of all new beetles (1866 species-group, 105 genus-group, six familygroup) were described in The Canadian Entomologist while the Memoirs of the Entomological Society of Canada included $17 \%$ of new beetle taxa (376 species-group, 31 genus-group, one family-group names). The Supplements of The Canadian Entomologist included 34 new speciesgroup and one new genus-group taxa.

New beetles were described in 67 families classified in the suborders Adephaga and Polyphaga (Supplementary Tables S1-S3). Ninety-four per cent of all new beetles were described in only 24 families (Fig. 2; note that families not in Fig. 2 included fewer than 10 new taxa each). Rove beetles (Coleoptera: Staphylinidae - e.g., Fig. 3) included the highest number of new species-group and genus-group names with 433 new taxa. Weevils (Coleoptera: Curculionidae), leaf beetles (Coleoptera: Chrysomelidae - e.g., Fig. 4), and scarabs (Scarabaeidae - e.g., Fig. 5) each had over 200 new beetles.

New species-group taxa published in The Canadian Entomologist and associated publications originated from 53 countries (Supplementary Table S1). More than $50 \%$ of new beetles $(n=1171)$ were described from the United States of America, with Canada $(n=465)$ and Mexico $(n=230)$ as the next most important sources of the new beetles (Fig. 6). The countries that served as the sources of specimens for three or more new species-group taxa (Fig. 6) are overwhelmingly from the New World with fewer new beetles originating from Asia (i.e., China, Vietnam, and South Korea).

\section{Authors of new taxa}

One hundred and sixty-five authors described new beetle taxa in The Canadian Entomologist and associated publications in the last 150 years (Supplementary Tables S1-S3). Authors who made the most significant contributions are listed in Table 1 and brief biographical notes for each are included below. Three authors (W.J. Brown, T. L. Casey, and J.M. Campbell) were the most productive, each describing more than 200 new beetle taxa in these publications. Between 100 and 200 new taxa were proposed by A. Smetana, H.C. Fall, W.S. Blatchley, H.F. Howden, and F.C. Bowditch. Between 20 and 100 new beetle taxa were described by 18 Coleopterists (Table 1). The number of scientific articles published by the 
Fig. 1. New Coleoptera described in The Canadian Entomologist, the Supplements of The Canadian Entomologist, and the Memoirs of the Entomological Society of Canada, by decade. New species-group (white bar), genus-group (grey bar), and family-group (black bar) taxa.

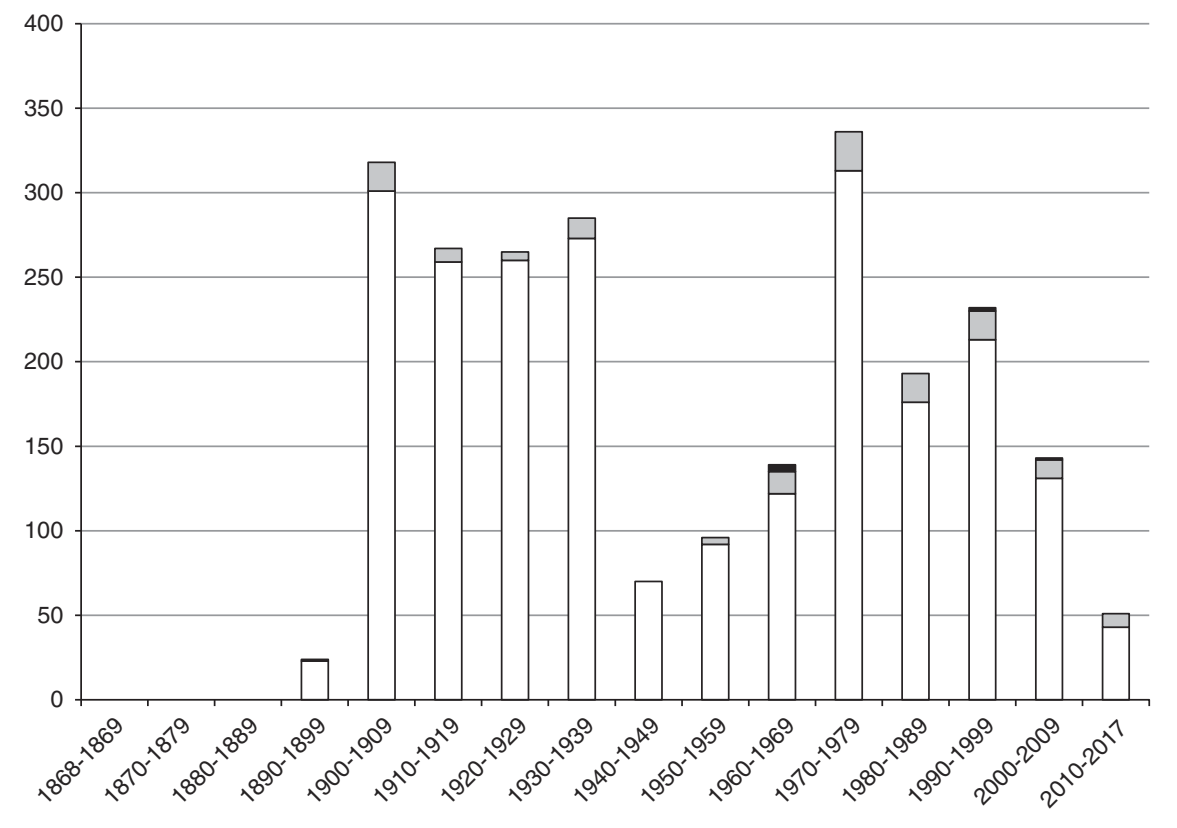

authors in Table 1 varied greatly, from a single monograph published by T.L. Erwin which included 44 new taxa, to a contribution of 291 new beetles in 66 smaller articles by W.J. Brown.

The authors of all new beetle taxa described in The Canadian Entomologist and associated publications in the last 150 years worked at institutions located in 20 countries (Fig. 7). The United States of America $(n=75,46 \%)$ and Canada $(n=42,26 \%)$ are by far the two countries that supported the highest number of authors of new beetles. Chinese institutions supported eight authors of new beetle taxa while various other countries supported up to four authors (Fig. 7).

\section{Brief biographical notes on Coleopterists who published 20 or more new taxa in The Canadian Entomologist and associated publications}

\section{Becker, Edward Coulton}

Ed Becker was born in March 1923 in St. Louis, Missouri, United States of America. After studies in Missouri and Illinois, serving in the United States Marine Corps, as well as working for two years as an entomologist at La Ceiba in Honduras, Becker joined the Entomology Division of what is now the Canadian National Collection of Insects, Arachnids, and Nematodes (Ottawa, Ontario, Canada) in June of 1952. In addition to his research on the taxonomy of click beetles (Coleoptera: Elateridae), Becker made important contributions as a volunteer to not-for-profit organisations (e.g., CanaColl Foundation) and scientific societies (e.g., Entomological Society of Canada, Coleopterists Society) during his career. Becker retired in December 1980 and died in Ottawa, Ontario in May of 2008 after continuing his work at the CNC for 27 years as a volunteer.

\section{Blaisdell, Frank Ellsworth}

Born in March 1862 in Pittsfield, New Hampshire, United States of America, Blaisdell moved with his parents to California, United States of America in 1870. He entered Cooper Medical College in San Francisco in 1887, and received, two years later, the 
Fig. 2. New Coleoptera described in The Canadian Entomologist, the Supplements of The Canadian Entomologist, and the Memoirs of the Entomological Society of Canada, by family. Only families with 10 or more new species-group taxa are included. A complete list is given in Supplementary Tables S1-S3. New species-group (white bar), genus-group (grey bar), and family-group (black bar) taxa.

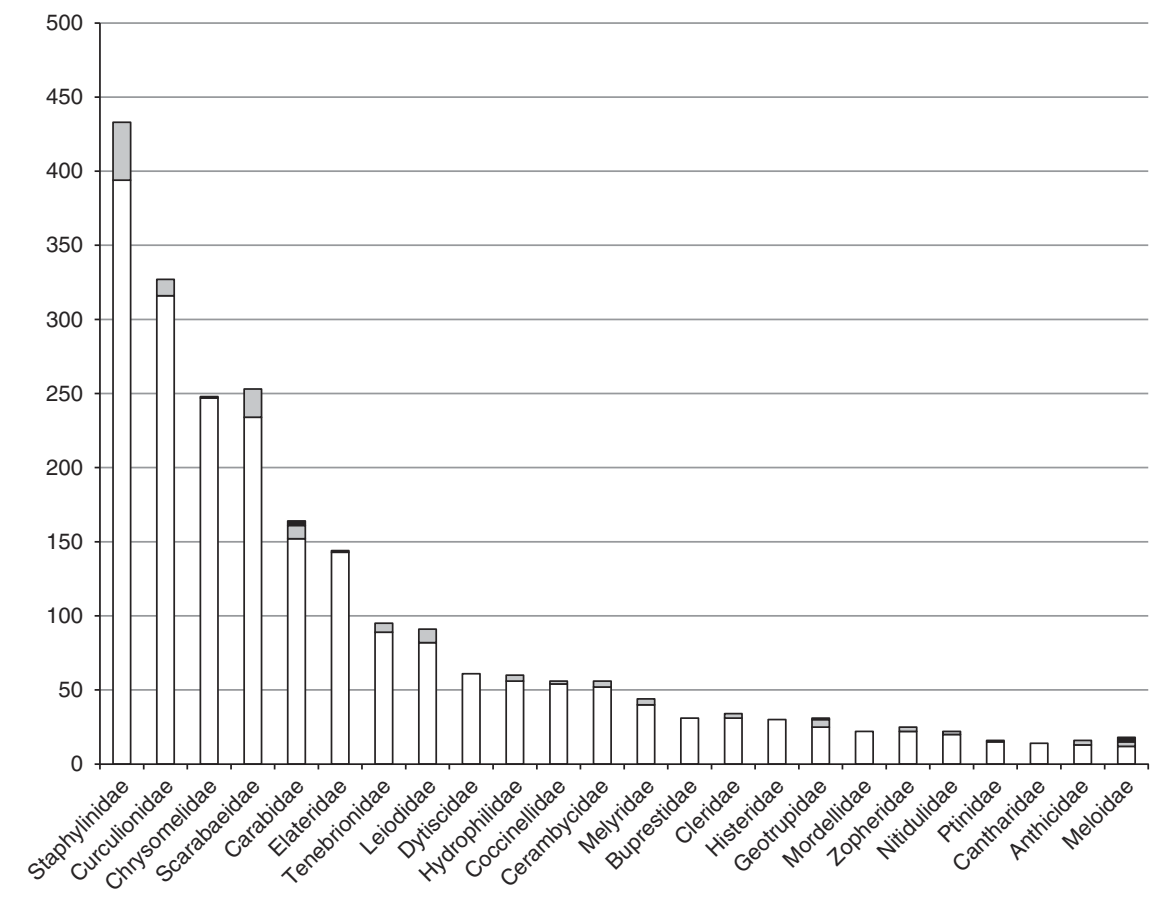

degree of Doctor of Medicine. He first practiced medicine in California before accepting an academic position at Cooper College in 1900, which eventually was absorbed by Stanford University. Ultimately, he became a professor of surgery and retired in 1927. As a hobby, he enjoyed collecting and studying Coleoptera, particularly Melyridae and Tenebrionidae. After his retirement, he worked at the California Academy of Sciences in San Francisco. He died in July of 1946.

\section{Blatchley, Willis Stanley}

Born in October 1859 in North Madison, Connecticut, United States of America, Blatchley taught various subjects and served as head of the science department in a high school in Terre Haute, Indiana, United States of America, from 1887 until 1894 when he was elected Indiana State Geologist under the Republican banner. Defeated in 1910 by the Democrats, he spent his remaining years mostly travelling, collecting, exploring, and writing. He wrote on several subjects but his main passion, besides philately, was entomology, particularly Orthoptera, Hemiptera, and Coleoptera. He died in May 1940 in Indianapolis, Indiana.

\section{Bowditch, Frederick Channing}

Born in June 1854 in Brookline, Massachusetts, United States of America, Bowditch worked as a lawyer and conveyancer like his father. As a hobby, he was interested in entomology, particularly Coleoptera, and accompanied Samuel Hubbard Scudder in Colorado and Wyoming, United States of America to collect fossils from Florissant shales. He died at his birthplace in October 1925.

\section{Bright, Donald Edward}

Born in February 1934 in Columbus, Ohio, United States of America, Don Bright joined the Entomology Research Institute, Department of Agriculture, in Ottawa, Ontario in March 1966 after being an assistant research entomologist with 
Fig. 3. Valdiviodes ashworthi Smetana, 1981 (Coleoptera: Staphylinidae). Smetana (1981) described this distinctive rove beetle from the Valdivian rainforest of Chile, an area remarkable for hosting relictual lineages of plants and animals. Since its discovery nearly 40 years ago, the taxonomic placement of the single species of Valdiviodes Smetana, 1981 continues to puzzle systematists with its peculiar combination of morphological character states. Smetana's comprehensive taxonomic research on poorly known rove beetle faunas, especially those of North America, China, Taiwan, and the Himalayas, have and continue to provide a critical backbone for an improved evolutionary understanding and reclassification of this diverse group of beetles.

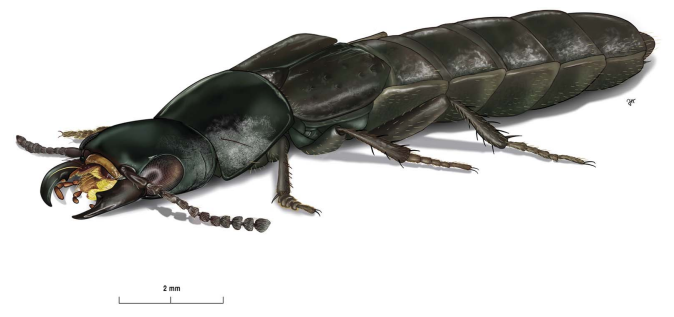

Fig. 4. Calligrapha knabi W.J. Brown, 1940 (Coleoptera: Chrysomelidae). Brown (1940) described this colourful Cornus Linnaeus (Cornaceae)-feeding leaf beetle based on its striking markings and divergent claws. He described C. knabi from the Gaspé Peninsula, Québec, and it remains among a minority of leaf beetle species that are recorded only from Canada. Brown was a taxonomic generalist, describing nearly 300 beetle species in 29 families, and was among the first authors to include genitalic drawings in his work. He described nine Calligrapha Chevrolat, 1836 species, which all remain taxonomically valid.

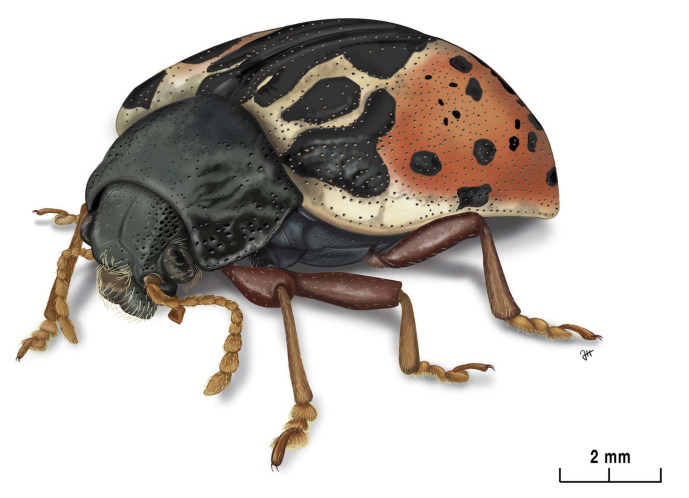

Fig. 5. Onthophagus cynomysi W.J. Brown, 1927 (Coleoptera: Scarabaeidae). W.J. "Bill" Brown was the first Coleopterist in the Systematic Entomology Division of the Department of Agriculture, which he joined in 1927. He was a pioneer in the use of biological concepts in the species-level recognition of beetles, and was interested in associating collected specimens with their hosts, often in unusual habitats, from the Arctic to the southern United States of America. He described Onthophagus cynomysi in 1927 based on specimens he collected the previous year in Noble County, Oklahoma, from prairie dog (Cynomys Rafinesque, 1817 (Mammalia: Sciuridae)) burrows (Brown 1927). As in many other dung beetles, only the males exhibit the horn-like extensions of the pronotum.

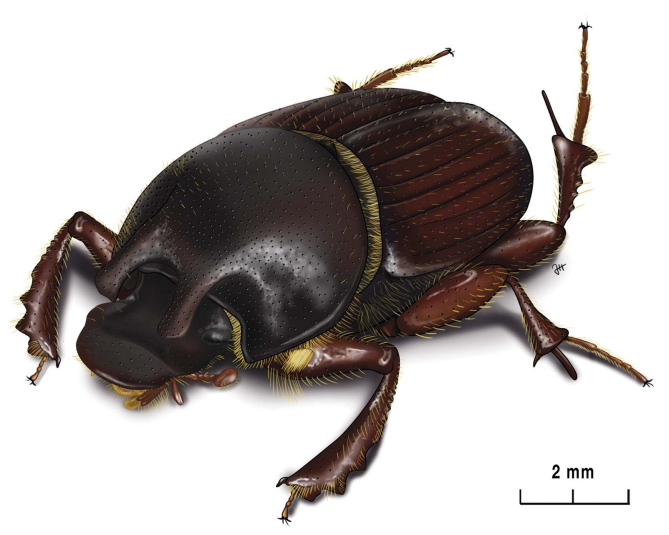

the University of California. He specialised on the study of bark beetles (Coleoptera: Curculionidae: Scolytinae) but he also wrote an identification book on the metallic wood boring beetles (Coleoptera: Buprestidae) of Canada and Alaska. He retired in 2003 and moved to Fort Collins, Colorado, United States of America where he continues systematics research on Scolytinae at the Colorado State University.

\section{Brown, Williamson James}

Bill Brown was born in August 1902 near Preston, Nebraska, United States of America, on the Sac and Fox Indian Reservation. He was hired in January 1927 to work as a Coleopterist for the Division of Systematic Entomology at the Department of Agriculture in Ottawa, Ontario. During his career, he worked mainly on the systematics of scarabaeoids, elaterids, and 
Fig. 6. Geographic origin of new species-group taxa described in The Canadian Entomologist, the Supplements of The Canadian Entomologist, and the Memoirs of the Entomological Society of Canada, as determined by the country of the name bearing type(s). Only countries with three or more new species-group taxa are included. A complete list is given in Supplementary Table S1. USA, United States of America; US Virgin Islands, United States Virgin Islands.

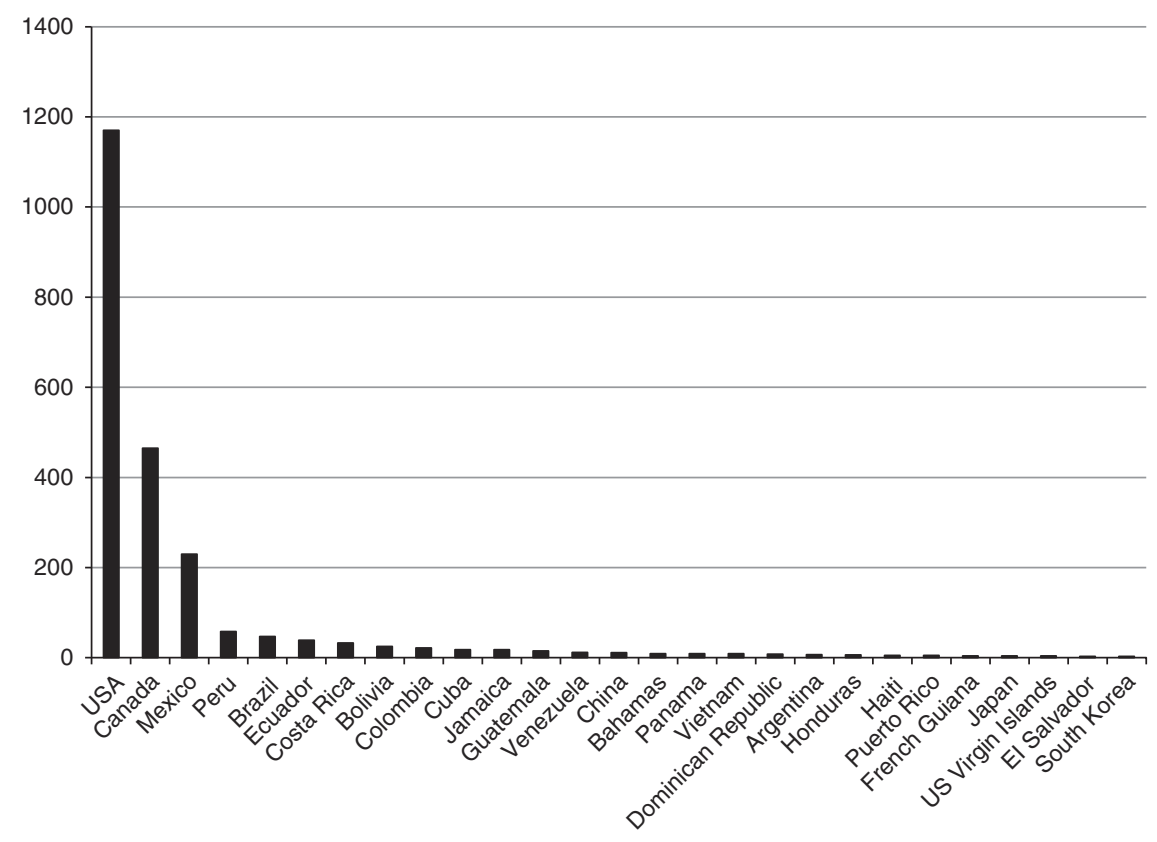

chrysomelids, on Arctic beetles, adventive species in North America, as well as on the problem of sibling species. He was editor of The Canadian Entomologist from 1939 to 1946. He retired in 1967 and died in May 1977 in Ottawa, Ontario.

\section{Campbell, John Milton}

Milt Campbell spent most of his career working on the systematics of Tenebrionidae: Alleculinae and of Staphylinidae. Born in December 1935 in Hopkinsville, Kentucky, United States of America, he worked from 1964 to 1966 in Guatemala where he studied the ecology and control of the coffee leaf miner, a Lepidoptera species considered one of the worst pest species of coffee. He joined the Biosystematics Research Institute, Department of Agriculture, in Ottawa, Ontario in August 1966 and retired in October 1993. He has collected beetles extensively throughout the New World and continues his systematics research on Alleculinae.

\section{Casey, Thomas Lincoln}

Born in February 1857 at West Point, New York, United States of America, Casey was a military officer and engineer by profession and an entomologist, conchologist, and astronomer. He graduated in 1879 from West Point Military Academy and until his retirement in 1912, at the age of 55 with the grade of Colonel, served in the Engineer Corps of the United States Army, working largely on river and harbour improvements. As an entomologist, he is well known for his controversial concept of species where little room was left for intraspecific variation. He died in February 1925 in Washington, District of Columbia, United States of America. His collection of more than 115000 specimens is held at the National Museum of Natural History in Washington.

\section{Cook, Joyce}

Joyce Cook was born in Yarmouth, Nova Scotia, Canada in November 1940. A lover of 
Table 1. Number of scientific articles published and number of new beetles described, by authors describing 20 or more species in The Canadian Entomologist and associated publications.

\begin{tabular}{lrccrr}
\hline Authority & Number articles & Species-group taxa & Genus-group taxa & Family-group taxa & Total \\
\hline Becker, E.C. & 8 & 25 & 0 & 0 & 25 \\
Blaisdell, F.E. & 8 & 20 & 3 & 0 & 23 \\
Blatchley, W.S. & 26 & 123 & 1 & 0 & 124 \\
Bowditch, F.C. & 12 & 107 & 0 & 0 & 107 \\
Bright, D.E. & 9 & 71 & 2 & 0 & 73 \\
Brown, W.J. & 66 & 279 & 11 & 0 & 290 \\
Campbell, J.M. & 31 & 183 & 18 & 0 & 201 \\
Casey, T.L. & 10 & 207 & 18 & 0 & 225 \\
Cook, J. & 8 & 62 & 2 & 0 & 64 \\
Erwin, T.L. & 1 & 39 & 4 & 1 & 44 \\
Fall, H.C. & 21 & 149 & 4 & 0 & 153 \\
Génier, F. & 4 & 40 & 3 & 0 & 43 \\
Howden, A.T. & 4 & 31 & 1 & 0 & 32 \\
Howden, H.F. & 35 & 95 & 16 & 1 & 112 \\
Klimaszewski, J. & 13 & 53 & 6 & 0 & 59 \\
Leech, H.B. & 10 & 21 & 0 & 0 & 21 \\
Liljeblad, E. & 3 & 22 & 0 & 0 & 22 \\
Morón, M.-Á. & 2 & 26 & 0 & 0 & 26 \\
Peck, S.B. & 13 & 67 & 5 & 0 & 72 \\
Schaeffer, C. & 8 & 31 & 0 & 0 & 31 \\
Smetana, A. & 19 & 179 & 14 & 0 & 193 \\
Stephan, K. & 1 & 21 & 2 & 0 & 23 \\
Swaine, J.M. & 14 & 57 & 0 & 0 & 57 \\
Wallis, J.B. & 7 & 22 & 0 & 0 & 22 \\
Wickham, H.F. & 5 & 20 & 0 & 0 & 20 \\
Wood, S.L. & 5 & 45 & 2 & 0 & 47 \\
\hline & & & & &
\end{tabular}

nature in general, she made significant contributions to the taxonomy of Coleoptera during her time working as a technician for Stewart Peck in the Department of Biology at Carleton University, Ottawa, Ontario between 1990 and 2017. Cook was an independent sheep farmer between 1970 and 1991. She continues to be passionate about beetles and is primarily focussed now on documenting the beetle fauna occurring on her property located south of Ottawa.

\section{Erwin, Terry Lee}

Born in December 1940 at St. Helena, California, Terry Erwin began his interest in entomology in his twenties. Soon he turned his attention to ground beetles (Coleoptera: Carabidae) and obtained his Ph.D. under George Ball at the University of Alberta (Edmonton, Alberta, Canada). After a postdoctorate at Harvard University (Cambridge, Massachusetts), he joined the staff of the Smithsonian Institution in
Washington, District of Columbia in 1970 where he still works on the systematics of ground beetles.

\section{Fall, Henry Clinton}

Fall was a high school teacher by profession and a Coleopterist by devotion. He first taught physics and mathematics in Chicago (Illinois, United States of America) schools. Health problems forced him to move to a warmer climate and he eventually left for California where he taught physics and chemistry in Pomona and Pasadena, California. He retired in 1917 and moved to Massachusetts. Over his life, Fall built one of the largest private beetle collections with an estimated 250000 specimens representing about $90 \%$ of the then known North American species (excluding those proposed by Thomas Casey). Born in Farmington, New Hampshire in December 1862, Fall died in 1939 in Tyngsboro, Massachusetts. 
Fig. 7. Institution of authors of new species-group taxa described in The Canadian Entomologist, the Supplements of The Canadian Entomologist, and the Memoirs of the Entomological Society of Canada, by country. Each author was assigned to the country of the institution where they performed most of their research. USA, United States of America.

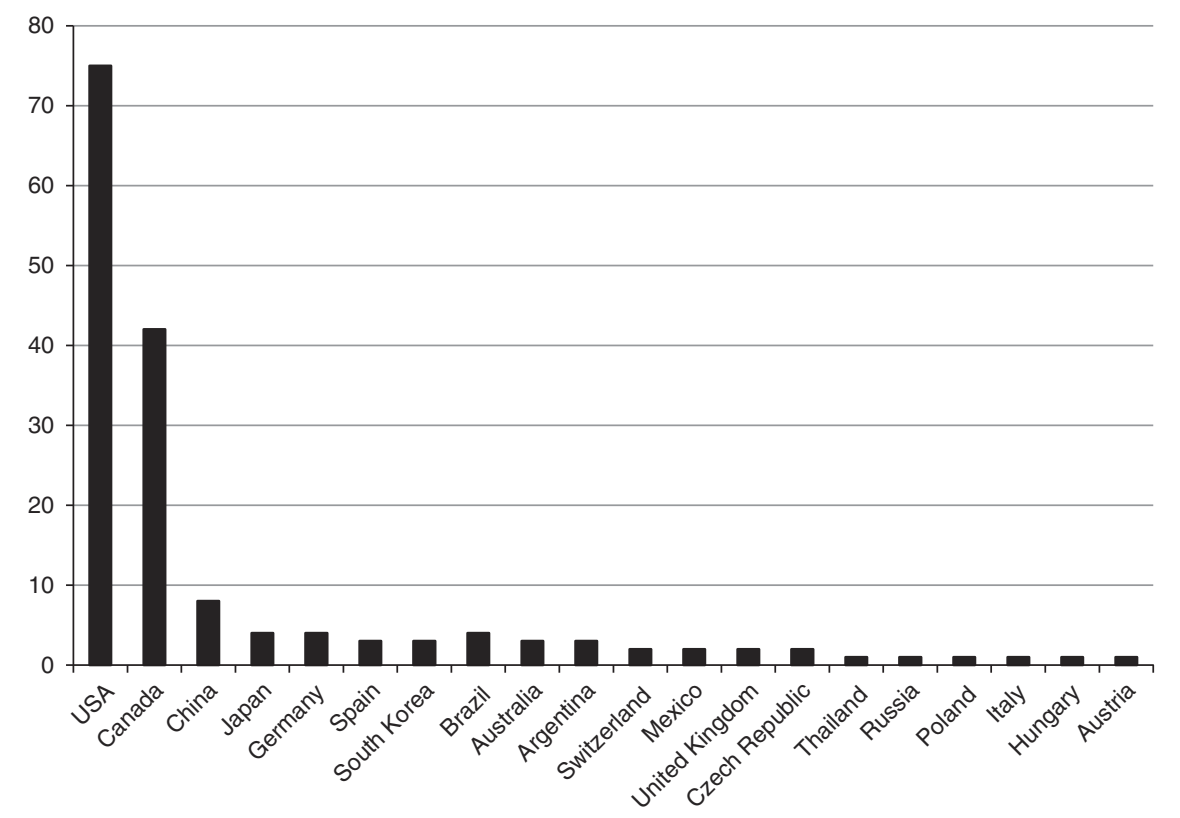

\section{Génier, François}

François was born in Montreal, Québec, Canada, in October 1960. He worked as senior technician at the Lyman Entomological Museum, Macdonald College of McGill University, SainteAnne-de-Bellevue, Québec, from 1982 to 1989 and has been the collection manager in entomology at the Canadian Museum of Nature, Gatineau, Québec since 1990. Although his interests are in dung beetles (Coleoptera: Scarabaeidae: Scarabaeinae), he started publishing on Aleocharinae (Coleoptera: Staphylinidae) with Jan Klimaszewski. He regularly goes on collecting expeditions abroad, particularly in Africa.

\section{Howden, Anne Elizabeth [née Thompson, published under the name A.T. Howden]}

Born in Baltimore, Maryland, United States of America, in July 1927, Anne moved with her husband Henry to Ottawa (Ontario) in 1957. She became a research associate with Carleton University and subsequently with the Canadian Museum of Nature and worked on the systematics of weevils (Coleoptera: Curculionidae), particularly on the diverse genus Pandeleteius. She died in September 2016 in Victoria, British Columbia, Canada.

\section{Howden, Henry Fuller}

Henry Howden was interested in entomology since his teenage years and dedicated his life to the systematics of scarab beetles (Coleoptera: Scarabaeoidea). Born in Baltimore, Maryland, in August 1925, he taught at the University of Tennessee in Knoxville (Tennessee, United States of America) after his graduation and before accepting a position with the Entomology Research Institute, Department of Agriculture, in Ottawa (Ontario) in August 1957. He resigned from this position in August 1970 to accept a full professorship in the Department of Biology at Carleton University, Ottawa. He and his wife Anne became research associates of the Canadian Museum of Nature and eventually donated their large beetle collection (mostly from the New World and Australia) and a financial endowment to the museum to support entomological research. Henry retired from Carleton University in 1995 
and died in May 2014 in Victoria, British Columbia.

\section{Klimaszewski, Jan}

Born in Wroclaw, Poland in August 1950, Jan worked as an assistant professor at the Museum of Natural History in Wroclaw (1977-1980), as a postdoctoral research fellow at the Biosystematics Research Centre, Ottawa, Ontario (1980-1982), as Postdoctoral Research Associate at the Lyman Entomological Museum near Montréal, Québec (1982-1989), as a Senior Curator of the Department of Coleoptera at the Transvaal Museum (currently the Ditsong National Museum of Natural History) in Pretoria, South Africa (1989-1993), as curator of Coleoptera at Landcare Research in Auckland, New Zealand (1994-1996), as scientist at British Columbia Research in Vancouver, British Columbia (1996-1998), and since 1998 as a research scientist and curator of the R. Martineau Insectarium at the Laurentian Forestry Centre in Ville de Québec, Québec. He continues to publish on the systematics of the diverse aleocharine rove beetles (Coleoptera: Staphylinidae: Aleocharinae).

\section{Leech, Hugh Bosdin}

Born in Kamloops, British Columbia in May 1910, Leech quickly developed an interest for entomology, especially beetles, and published his first paper at the age of 20 . He eventually became a leading authority on the systematics of water beetles. His employment at the Forest Entomology Laboratory in Vernon, British Columbia, from 1930 to 1947, was interspersed with studies, first at the University of British Columbia for his bachelor's degree and then at the University of California in Berkeley (California) for his Master of Science degree. He moved to California in 1947 to work as an assistant curator in the Entomology Department of the California Academy of Sciences. Hugh Leech retired in 1975 and died in California in November 1990.

\section{Liljeblad, John Emil [published under the name E. Liljebad]}

Little is known about Liljeblad's life. He was born in 1861 in Sweden, possibly on the island of Öland. He worked as an assistant curator at the Chicago Natural History Museum (currently the Field Museum) (Chicago, Illinois) from 1915 until his retirement in 1940. He published mainly on the taxonomy of tumbling flower beetles (Coleoptera: Mordellidae). He died in October 1953 in Van Nuys, California.

\section{Morón, Miguel-Ángel}

Born in October 1952 in the capital of Mexico, Miguel-Ángel, a talented artist, was associated his entire career with the Instituto de Ecología from 1984 onwards, first in Mexico City and later in Xalapa, Veracruz, Mexico. His main interest was the subfamily Melolonthinae (Coleoptera: Scarabaeidae) and most of his publications deal with the taxonomy, natural history, phylogeny, and larval morphology of Latin American species. He died in August 2017.

\section{Peck, Stewart Blaine}

Stewart Peck is professor emeritus at the Department of Biology, Carleton University, in Ottawa, Ontario. As a taxonomist he is particularly interested in leiodid beetles (Coleoptera: Leiodidae) and carrion beetles (Coleoptera: Silphidae) but he also has a deep interest in cave beetles and in the fauna and biogeography of the islands of the West Indies and the Galápagos Islands. Born in Davenport, Iowa, United States of America, in August 1942, he studied at Harvard University, Cambridge, Massachusetts. He moved to Ottawa in September 1970 and retired as full professor at Carleton University in June 2014. He continues his systematics research on Leiodidae and Silphidae as a research associate at the Canadian Museum of Nature and the Canadian National Collection of Insects, Arachnids, and Nematodes.

\section{Schaeffer, Charles Frederic August [published under the name C. Schaeffer]}

Schaeffer was born in June 1860 in London, United Kingdom. In 1898, he worked as assistant to William Beutenmüller, curator at the American Museum of Natural History, and from 1902 as curator of the insect collection at the Museum of the Brooklyn Institute of Arts and Sciences (New York, New York). A descriptive taxonomist, he published on several beetle families but showed a particular interest for Chrysomelidae (Coleoptera). He died in August 1934 in New York. 


\section{Smetana, Aleš}

Born in April 1931 in Hradec Králové, Czechoslovakia [now Czech Republic], Aleš Smetana became fascinated with beetles at a young age. After graduating as a doctor of medicine, he worked at the Institute of Parasitology at the Czechoslovak Academy of Sciences from 1960 to 1970 . After a postdoctorate fellowship in Ottawa, Ontario (1967-1969), he joined the Entomology Research Institute, Agriculture Canada, in Ottawa in September 1971 where he worked mainly on the systematics of Staphylinidae and Hydrophilidae (Coleoptera). He retired in December 1999 but assiduously continues his research on Staphylinidae.

\section{Stephan, Karl Heinz [published under the name K. Stephan]}

Karl Stephan will be remembered as one of the most skilled beetle collectors of his time. He collected in Ontario, Arizona (United States of America), and particularly in Latimer County, Oklahoma, United States of America, where he spent 30 years. Born in May 1931 in what would become East Germany, he immigrated to Windsor, Ontario, in 1952. He died in June 2005 in the town of Red Oak in Latimer County. He was a tool and die maker but very little is known about his professional activities except that his obituary mentioned that his "career path was in engineering".

\section{Swaine, James Malcolm}

Swaine was primarily a forest entomologist and is considered to have laid the foundations for forest entomology research and bark beetle (Curculionidae: Scolytinae) research in Canada. Born in Barrington, Nova Scotia in 1878, he worked as assistant in entomology and zoology at Cornell University (Ithaca, New York) from 1905 to 1907. After lecturing for five years in the same fields at Macdonald College of McGill University, in Sainte-Anne-de-Bellevue, Québec, he was appointed in 1912 as Officer-in-Charge of the Forest Insect Section of the Division of Entomology, Ottawa (Ontario). In 1923, he became Associate Dominion Entomologist and in 1934 Director of Research for the Department of Agriculture. Finally, in 1937, he worked for the Directorate of Science Service. He died in November 1955 at his home in Ottawa.

\section{Wallis, John Braithwaite}

Wallis was born at Erith, London, United Kingdom, in December 1876. He immigrated to Canada in 1894 and spent the rest of his life in Manitoba. After teaching a few years, he became Supervisor of Nature Study for Winnipeg Schools and later was appointed assistant superintendent of the Winnipeg Public Schools. As an amateur entomologist, he was mainly interested in Odonata, Lepidoptera, and Coleoptera, particularly water and tiger beetles. He died in Winnipeg in March 1962.

\section{Wickham, Henry Frederick}

Wickham was born in Shrewton, Wiltshire, United Kingdom in October 1866 and died in Iowa City, Iowa in November 1933. He moved with his parents to Iowa City in 1871 and received his Master of Science degree in 1894 from the State University of Iowa. From 1891 to 1903, he worked as an instructor and associate professor at the University and from 1903 to 1933 as professor of entomology. For many years Wickham collected fossil insects at Florissant in Colorado.

\section{Wood, Stephen Lane}

Born in Providence, Utah, United States of America in July 1924, Steve Wood showed an interest in bark and ambrosia beetles (Coleoptera: Curculionidae: Scolytinae) in his youth and spent the rest of his life working on the systematics of these important forest beetles. He joined the Systematic Entomology Unit, Department of Agriculture, Ottawa (Ontario) in November 1953 and left in August 1956. The same year, he accepted the position of assistant professor in the Department of Zoology and Entomology at Brigham Young University, in Provo, Utah, where he remained until he died in July 2009.

\section{Discussion}

\section{Trends over time: extrinsic influences}

Of the notable socio-political events of the 20th Century (e.g., World War I: 1914-1918; Great Depression: 1930s; World War II: 1939-1945; Cold War: 1947-1991), World War II seems to coincide most closely with a significant change in the number of beetles described in The Canadian Entomologist and associated publications. Although 
the rate of taxon descriptions did not decrease during the Great Depression (unlike North American Tenebrionidae species descriptions, Bousquet et al. 2018: Fig. 1), fewer beetles were described during the 1940s as entomologists and trainees joined the war effort or performed supporting applied research (Fig. 1). This drop was followed by a slow recovery in the following decades.

The overall number of Coleopterists employed over time could certainly affect the number of new taxa described in scientific literature. The number of beetle specialists employed at the Canadian National Collection of Insects, Arachnids, and Nematodes (Ottawa, Ontario), for example, has fluctuated over time (Lonsdale and Huber 2011). While government scientists are only a subset of taxonomists who have described new taxa in The Canadian Entomologist and associated publications, some have contributed significantly to the numbers of new taxa reported here (e.g., W.J. Brown, E.C. Becker, D.E. Bright, J.M. Campbell, J. Klimaszewski, A. Smetana) and their major contributions are summarised in Table 1. Recent changes in the publishing landscape (e.g., the emergence of taxonomically focussed journals such as Zootaxa in 2001 and ZooKeys in 2008) have also affected the number of taxonomic submissions to The Canadian Entomologist over that last two decades. The appearance of the open access, rapidly produced journal ZooKeys, for example, which is dedicated to publishing taxonomic and systematics studies, has been a popular outlet for articles that include descriptions of new taxa. In the first seven years after its launch in 2008, ZooKeys had already published 500 issues including 65942 pages in 2436 articles (Erwin et al. 2015).

\section{Trends over time: intrinsic influences}

Publication of the Memoirs of the Entomological Society of Canada, which was a popular outlet for longer articles such as taxonomic revisions since 1963, ceased in 1997 due to financial and other considerations. As mentioned above, the opportunity to publish larger taxonomic monographs subsequently became available again elsewhere with the appearance of Zootaxa and ZooKeys. It is outside the scope of this review to assess the effects of editorial changes on the number of new beetle taxa described over time in The Canadian Entomologist. However, we note that the "Instructions to contributors" for the journal specifies that "Single species descriptions, without significant value-added components (e.g., richly illustrated key, phylogenetic analyses), will not be considered". This stipulation would seem to limit future descriptions of new taxa in the journal. Conversely, the journal does not have page charges and does not charge for colour plates (although authors can opt to pay a fee to make their article open access). This "no fee" policy, in place since 2012, should serve to increase submissions of longer taxonomic works.

\section{Conclusion}

Although The Canadian Entomologist and its associated publications have long been considered to be important in documenting the beetle fauna of Canada, we have demonstrated that these outlets have also been significant in documenting new discoveries in the United States of America as well as a large number of other countries. These publications have been used by many specialists from Canada, the United States of America, and a number of other countries who published on a broad number of taxonomic groups. Journals must constantly have to adapt to extrinsic and intrinsic changes in order to remain relevant in a competitive marketplace. We believe that The Canadian Entomologist will continue to be coveted as a suitable outlet for taxonomic works in the future.

\section{Supplementary material}

To view supplementary material for this article including full lists of taxa described with bibliographic information, please visit https://doi.org/ 10.4039/tce.2018.48

\section{Acknowledgements}

The authors thank Jessica Hsiung (Agriculture and Agri-Food Canada, Canadian National Collection of Insects, Arachnids, and Nematodes, Ottawa, Ontario, Canada) for producing the illustrations for this project. Yves Bousquet (Gatineau, Québec, Canada) assisted with various aspects of this article. Three anonymous 
reviewers provided constructive comments on an earlier version of this manuscript.

\section{References}

Bethune, J.S. 1868a. Introductory. The Canadian Entomologist, 1: 1-2.

Bethune, J.S. 1868b. A luminous larva. The Canadian Entomologist, 1: 2-3.

Bouchard, P., Bousquet, Y., Davies, A.E., AlonsoZarazaga, M.A., Lawrence, J.F., Lyal, C.H.C. et al. 2011. Family-group names in Coleoptera (Insecta). ZooKeys, 88: 1-972.

Bousquet, Y., Bouchard, P., Davies, A.E., and Sikes, D.S. 2013. Checklist of beetles (Coleoptera) of Canada and Alaska, 2nd edition, Pensoft Publishers, Sofia, Bulgaria.

Bousquet, Y., Thomas, D.B., Bouchard, P., Smith, A. D., Aalbu, R.L., Johnston, M.A., and Steiner, W.E. 2018. Catalogue of Tenebrionidae (Coleoptera) of North America. ZooKeys, 728: 1-455.

Brown, W.J. 1927. Four new-species of Onthophagus (Coleoptera). The Canadian Entomologist, 59: 128-133.

Brown, W.J. 1940. Some new species of Cantharidae and Chrysomelidae (Coleoptera). The Canadian Entomologist, 72: 161-166.
Erwin, T., Stoev, P., Georgiev, T., and Penev, L. 2015. ZooKeys 500: traditions and innovations hand-inhand servicing our taxonomic community. ZooKeys, 500: $1-8$.

Floate, K.D. and Huber, D. 2018. Congratulations to The Canadian Entomologist on this, its sesquicentennial anniversary!. The Canadian Entomologist, 150: $1-11$.

International Commission on Zoological Nomenclature. 1999. International code of zoological nomenclature, 4th edition, International Trust for Zoological Nomenclature, London, United Kingdom.

International Commission on Zoological Nomenclature. 2012. Amendment of Articles 8, 9, 10, 21 and 78 of the International Code of Zoological Nomenclature to expand and refine methods of publication. ZooKeys, 219: 1-10.

Lonsdale, O. and Huber, J.T. 2011. Insect collections of Canada series: Canadian National Collection of Insects, Arachnids \& Nematodes, Ottawa. Newsletter of the Biological Survey of Canada, 30: $15-40$.

Smetana, A. 1981. A new genus and species of Quediini from Chile (Coleoptera: Staphylinidae). The Canadian Entomologist, 113: 349-354. 